\title{
The Implementation of Quality Management Integrated in Improving the Quality of Learning in the Classroom
}

\author{
Indra Lesmana \\ Department of Educational Administration \\ Universitas Negeri Malang, Indonesia \\ lesmanaindra197@gmail.com
}

\author{
Mustiningsih \\ Department of Educational Administration \\ Universitas Negeri Malang, Indonesia \\ mustiningsih.fip@um.ac.id
}

\begin{abstract}
This study aims to: (1) clarify the application of Total Quality Management (TQM) in improving the quality of teaching in the classroom; (2) assisting teachers in determining innovative learning; and (3) increasing the activeness of students with innovative learning. The method used in this research is a literature review, by analyzing library materials both research and book. The final results of this study can later be made into recommendations that the application of TQM is very necessary for determining the quality of learning in the classroom.
\end{abstract}

Keywords: innovative learning, students, total quality management, quality of learning

\section{INTRODUCTION}

Education is one of the parts that often experience problems when viewed in detail. Education becomes one of the benchmarks to see the progress of a nation. Following Law Number 20 of 2003 concerning the System National Education article 1 that education is a planned business by adults in which a learning process occurs to assist students in developing their potential. School is a building or place where education takes place and a learning process is carried out in which there are educators and educational staff. Based on the presentation from Sutari in [1] states that there are five educational factors that to each other influence and relate, the five factors include the goal factors, educators, students, tools, and the natural surroundings. Educators are one component of education that plays an important role in the learning process both in the classroom and outside the classroom.

The development of science and technology which is the effect of globalization does not rule out the possibility of creating innovative learning following the era. The 21 st-century generation that is now commonly referred to as millennials who are accustomed to technology, will feel bored with learning that is monotonous and not innovative. Many educators have reached old age still using lecture learning, this is sometimes seen as boring learning because it does not keep up with the times. Appropriate learning for addressing and preparing millennial generation is learning that is for thinking, for doing, for being, and for living together [2]. Learning can be defined as a process that occurs between students and teachers by utilizing learning resources that can be obtained individually or directly from the teacher [3].

Following the opinion of [3] it can be concluded that learning also mus to observe changes in the environment, this environmental change is included by observing technological developments. After the learning component itself consists of educational goals, educators, students, learning media, methods learning, teaching materials, learning resources, and evaluation. The eight components if already fulfilled do not rule out the possibility of creating effective learning and efficient, but in fact in schools sometimes these components cannot be maximized, due to the quality of educators themselves who are less capable in managing classroom learning, lack of media and materials teaching that does not support the learning process, educators who are less updated about the times, or from students who are less active in the process learning.

Based on the description later, it can affect the quality of a learning process that results in students not optimally absorbing the knowledge provided by the teacher. Responding to this matter, TQM can be applied in improving the quality of learning, of course, this must be supported by several factors such as capable leaders, teachers who are always sensitive to the changing times, facilities school and infrastructure, as well as all components that support the implementation of learning. To maintain the quality of learning, it must start from developing human resources first, bearing in mind that human resources themselves are the potential that plays an important role in organizing innovative learning [4].

The role of TQM itself can later be used to redesign the implementation of learning and as a benchmark for teachers in determining the direction of learning so that it does not rule out the possibility of creating innovative learning so that learning can be improved in quality. This study aims to answer the problems that often arise related to the quality of learning. The concept of TQM itself is to ensure customer satisfaction with the quality of a product, in the world of education, the product in question is a service that concerns about education which also involves learning activities. The existence of the application of TQM is also expected to help teachers to facilitate the implementation of the learning process and is also expected to attract the activeness of students in following the learning process.

\section{METHOD}

This study used a qualitative descriptive approach. This approach will produce descriptive data in the form of written or oral words. Descriptive research was conducted to obtain an overview of the implementation of TQM in improving the quality of learning in the classroom. Data collection is done by conducting a study of some written literature such as articles and journals both research and non-nature research in, supported also by scientific reference books. The purpose of review literature is to construct and integrate the results of previous studies by 
looking at current conditions.

\section{RESULTS}

Research-based on the study and analysis of data through the literature review hopes to answer the research objectives described above before, namely: (1) explaining the application of TQM in improving the quality of learning in the classroom; (2) helping teachers determine innovative learning; and (3) increase the activeness of students with innovative learning. Based on the first research objective, namely the application of TQM in improving the quality of learning in the classroom. In accordance with the concept of TQM itself, namely the activity or effort to maintain the quality of quality so that customer satisfaction is always considered.

The learning activities themselves must at least be designed as attractive as possible following the standards set by the school. Principals as leaders in schools must empower teachers as effectively as possible in managing learning, always giving direction to teachers to stick to the vision and mission of the school in creating quality learning so that later the quality of these learning activities can be maintained. Principals must also be sensitive in terms of human resource development especially teachers through education and activities regular training.

These teacher education and training activities can be through workshops, seminars, or through supervision activities whose aim is to create human resources quality in conceptual abilities, technical abilities, theoretical abilities and can later be sensitive to the times. This includes the implementation of the TQM concept, especially in developing human resources owned by schools. The principal as a quality controller can also occasionally visit the class to see and assess the learning process and later be able to provide input to teachers, especially in terms of improving the quality of learning. The principal can also hold regular meetings that will later be held sharing and discussion related to the process of organizing learning in class, in this meeting will later be created views in the minds of teachers to always maintain the quality of the learning itself. The teacher must also be able to maximize the facilities and infrastructure available in learning activities this will later be able to encourage to learning create fun.

The second objective of this research is to help teachers create innovative learning. Innovative learning that always follows the times is learning that can be said to be successful. The application of the TQM concept also needs to be supported by several factors such as the condition of teachers, students, materials and media learning as well as the involvement of school leaders. The condition of teachers in implementing learning to support the implementation of TQM is sometimes still not $100 \%$ said to be ready, given the teacher's ability and age of the teacher who cannot be generalized. Improving the quality of teachers can be through training activities, it aims to develop the potential of the teacher himself so that later can organize innovative and interesting learning.

Innovative and interesting can learning influence the results of the learning process itself, because of the essence of the teacher himself as a facilitator in learning. Learners are the main focus in organizing learning, the purpose of learning itself is to assist students in developing their potential covering three domains, namely psychomotor, affective and cognitive. The readiness of learning materials and media is also an important component if you want to organize the learning process. The existence of media and learning materials that are ready can help teachers to organize learning in class and can attract the attention of students to participate in learning. The principal is one of the driving units, in this case, the principal must be able to participate in the organization of learning.

The final aim of this study is to increase student activity with innovative learning. The existence of innovative learning which is the implementation of TQM itself is expected to be able to attract the interest of students. The task of the teacher himself is not merely to teach but also to educate. Educating has a lot of activities not only focused on the delivery of teaching materials but also must observe the development process of students both mindsets, behavior, and spirituality. Teachers must always be sensitive in managing to learn in the classroom by approaching students, giving questions on the sidelines of the delivery of material or can provide rewards to students who are active in class. It is also the implementation of TQM, which is to provide satisfactory services to students so that they always feel cared for in the learning process in class so that learning in class will run effectively and efficiently.

\section{DISCUSSION}

\section{The Implementation of Total Quality Management (TQM) in Improving the Quality of Learning in Classes}

TQM is a series of activities that seek to improve and maintain the quality of quality so that later it can satisfy the customer. The application of TQM is not only in the field of companies or industrial factories, but in the present era, the implications of the application of TQM have penetrated the field of education. Implementation of TQM has been done but it still has not shown satisfactory results when it comes to the field of education, especially in organizing quality learning. Quality learning itself requires a long process, needs to be done in stages and sustainability, and requires human and non-human resources adequate [5]. The role of the principal info staring teachers is regularly necessary to create quality human resources and always pay attention to the quality of education quality.

Following the opinion of Juran [6], TQM is an activity that seeks the role of leaders in making continuous improvements and innovations by maximizing the resources owned by companies or institutions. This explanation is supported by the opinion of Sallis [7]. One of the efforts of school principals as educational leaders in maintaining quality is to provide education in quality concepts and lessons such as building work teams, management processes, service customer, communication and leadership. Improving the ability of teachers is expected to be able to provide good services to students, especially in the learning process in the classroom by following the times. [8] that with the training there will be a conceptual ability where the teacher can predict everything that happens and to achieve a goal. The 
principal is very instrumental in determining the quality of learning carried out by teachers in the classroom.

\section{Assist Teachers in Determining Innovative Innovative}

Learning is also needed to attract students' interest in learning. The competence pedagogical of the teacher is very important in organizing learning, in this case, the teacher is a facilitator for education customers, namely students. Implementation of TQM to improve learning can be done negotiations between teachers and students, this aims to introduce learning methods to students, this method must also be supported by teachers competent.

The principal can also include educators who are less competent in training. The training aims to develop the potential of the teacher which will influence work [9]. The existence of training for educators is also an effort to implement TQM to maintain the quality of learning. Training is also useful for preparing teachers, whom modern can keep up with the times. The teacher is expected to be able to use media electronica learning because this is following the characteristics of students who are not the same in capturing learning. The use of technology is a form of innovative learning that can be done by teachers, seeing the current conditions do not rule out the possibility that no child will stutter about technology and most will be able to operate it. The implementation of TQM in maintaining the quality of learning can also be highlighted from the view of
Abraham Maslow, known as the theory of human needs in which there is a need for appreciation [10].

The application of TQM in ensuring the quality of learning can also use the theory introduced by Edwards Deming, namely zero defects, which means minimizing the occurrence of errors or according to him is better to prevent than to treat in maintaining the quality of quality [11]. It should always be used as a benchmark that the possibility of error is $0 \%$ in the mind of a teacher, this is useful for creating innovative and creative learning, as well as an effort to implement TQM in ensuring the quality of learning in the classroom. Teachers in guaranteeing $0 \%$ error in learning, can do several things such as checking the readiness of students in participating in learning activities, this is because students are the focus main of learning activities.

The teacher must also prepare teaching materials and media that are following the theme of learning, the teacher can create conducive classroom conditions that are certain in the organization of learning, and the teacher must also provide a follow-up of the material that has been delivered. Teachers must also frequently conduct evaluations periodic of learning already carried out in class, teachers can also exchange information or ask for help from the principal in this matter. The following can be illustrated through the model of waterfall implementing TQM in improving the quality of learning and also helping teachers organize innovative and creative learning.

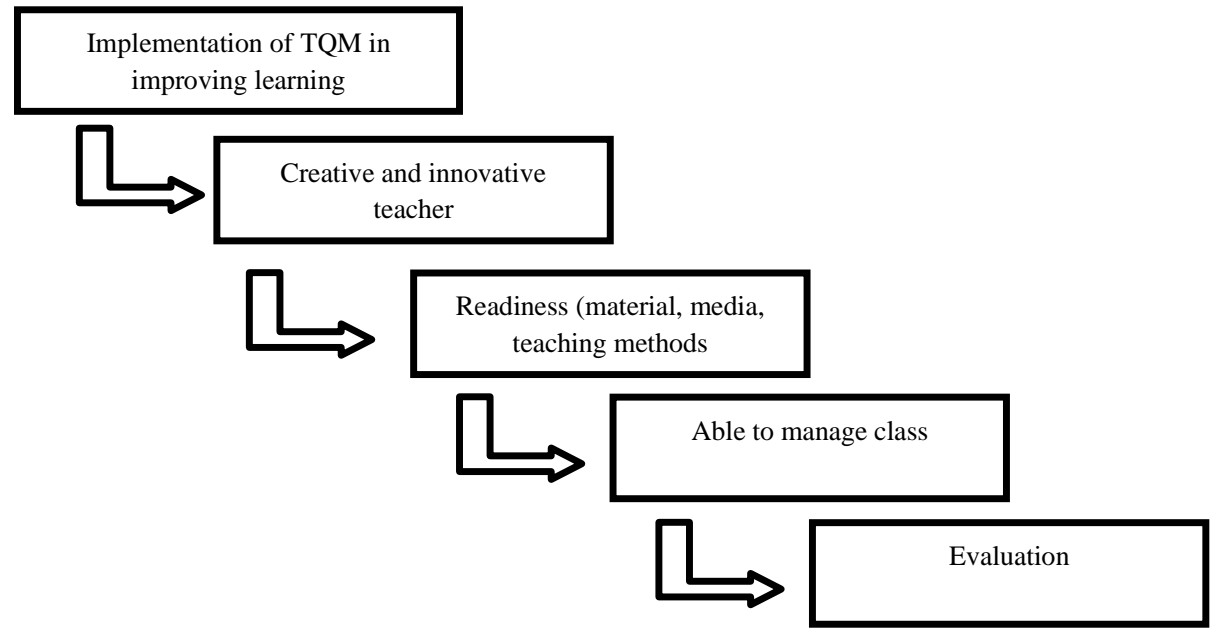

Figure 1

Illustrated Through the Model of Waterfall Implementing TQM

From the exposure to the model waterfall above, it can be seen that in addition to the teacher preparing himself for the learning process, class management is also needed to organize the learning process. Learning evaluation is needed to find out the mistakes or shortcomings of the teacher in organizing learning. The evaluation itself can be done by the teacher and the principal.

The manifestation of the principal's evaluation action can be done directly monitoring the learning done by the teacher in the classroom, this in addition to the supervision material for the teacher will also increase the motivation of the teacher in managing to learn. The principal also needs to involve a stake holder's school to participate in improving the quality of learning.

\section{Increasing Student Activity with Innovative Learning}

The activeness of students in learning activities is influenced by several factors according to the opinion of [12], namely the condition of weak students, the lack of focus teachers in teaching and the absence of attention from the teacher in the teaching process. Through the application of TQM, it is expected that teachers can maximize themselves in activities classroom management, especially learning. The teacher can also involve students in small discussions to find out the response of the learning that has been done by the teacher. 
Other efforts to use PAKEM learning are active, creative, effective and fun learning, this is the result of training for teachers to always be proactive in organizing innovative learning [13]. Teachers can apply approach rewards and punitive to learning, which in turn can motivate students to always be active in learning. The form of the reward itself has many types, it does not have to be material or material. Verbal and nonverbal behavior can also be classified as a form of reward teacher to students. The reward for students who are active in learning will motivate other students, this does not rule out the possibility that the teacher has created fun learning by involving all students.

\section{CONCLUSION}

The purpose of this study is basically to provide an overview of learning effective and efficient to readers so that it can be used as recommendations in improving learning in the classroom. From the description above, the researcher can conclude that the key to success in maintaining the quality of learning is primarily from the principal and educators themselves. The application of TQM in schools must be considered by the principal to maintain the quality of learning in the classroom by maximizing the role of teachers involved in these activities. The teacher becomes a central role in organizing the learning process.

The principal must also be able to maximize his role as an education manager to be able to maximize the resources owned by the school. Activities to assist teachers in determining innovative learning researchers have explained in the form model waterfall in which thein the model will be a continuous fall down. The principal also plays a role in improving the quality of learning through supervision activities which will later be used by teachers who need it, or the school principal can also include teachers in activities training. It is intended that teachers continue to improve their ability to manage and organize quality and learning innovatively.

The conclusion in increasing the activity of teacher students can conduct small discussions so that students can play an active role in learning activities. The teacher must also be able to enrich learning models that are fun for students so that students do not feel bored. The use of audiovisual equipment also will be able to attract students' interest in participating in learning to start from the beginning to the end.

\section{REFERENCES}

[1] Triwiyanto, T. 2015. Pengantar Pendidikan. Jakarta: Bumi Aksara.

[2] Lestari, B. 2008. Peningkatan Kualitas Pembelajaran dengan Model Pembelajaran Cooperative Learning. Retrieved May 2, 2019, from https://media.neliti.com/media/publications/17221ID-peningkatan-kualitas-pembelajaran-dengan-modelpembelajaran-cooperative-learning.pdf.

[3] Mustiningsih. 2017. Sistem Belajar Mengajar. Malang: Universitas Negeri Malang.

[4] Suyitno. 2016. Peningkatan Sumber Daya Manusia Melalui Penerapan Total Quality Management. Jurnal Akuntansi, Ekonomi dan Manajemen Bisnis, 2(2), 1-13.

[5] Supriyanto, A. 2011. Implementasi Total Quality Management dalam Sistem Manajemen Mutu Pembelajaran di Institusi Pendidikan. Retrieved May 2, 2019, from https://journal.uny.ac.id/index.php/cp/article/view/4188.

[6] Wani, I. A., \& Mehraj, H. K. 2014. Total Quality Management in Education: An Analysis. International Journal of Humanities and Social Science Invention, 14, 71-78.

[7] Rohman, N. 2017. Peran Kepala Sekolah dalam Peningkatan Mutu Pendidikan Perspektif Manajemen Mutu Terpadu Studi Kasus di Sdit Bumi Kartini Jepara. Jurnal Tarbawi, 14(2), 1-14.

[8] Robbins, S. P., \& Coulter, M. 2010. Manajemen. Jakarta: Erlangga.

[9] Ulfatin, N., \& Triwiyanto, T. 2016. Manajemen Sumber Daya Manusia Bidang Pendidikan. Jakarta: PT RajaGrafindo Persada.

[10] Syukron, B. 2016. Implementasi Manajemen Mutu Terpadu (Studi Transformatif pada Perguruan Tinggi. Retrieved May 2, 2019, from

journal.stainkudus.ac.id\%2Findex.php $\% 2$ FjurnalPenelitian $\% 2$ Fart icle\%2Fdownload\%2F1783\%2Fpdf\&usg=AOvVaw3kToQ1K_2 KraCWG16r3ZjK.

[11] Sallis, E. 2011. Manajemen Mutu Terpadu Pendidikan. Jogjakarta: IRCiSod.

[12] Crawford, L. E. 1999. Total Quality Management in Education: Problems and Issues for the Classroom Teacher. International Journal of Educational Management, 17, 67-73.

[13] Suhartoni, O. M. 2016. Upaya Meningkatkan Kualitas Pembelajaran dengan Pendekatan PAKEM Guru Kelas 4, 5, 6 Melalui Supervisi Kelas di SDN 3 Tlogosari Kecamatan Sumber Malang Kabupaten Situbondo Semester 1 Tahun 2015/206. Retrieved May 2, 2019, from jurnal.unej.ac.id\%2Findex.php $\% 2$ Fpancaran $\% 2$ Farticle $\% 2$ Fdown load $\% 2$ F2607\%2F2101\%2F\&usg=AOvVaw20gJjcIOzC3t5CxDxJ7-i. 